\title{
Theoretical Review of Entrepreneur and Social Entrepreneurship Concepts
}

\author{
Revisión Teórica de los Conceptos Emprendedor y Emprendimiento Social \\ María Dolores Martínez García a José María Moreno Meneses ${ }^{b}$ Karina Valencia Sandoval ${ }^{\mathrm{c}}$
} \begin{abstract}
:
This article includes a theoretical review of Social Entrepreneurship (SE) due to the gradual increase in the need for new businesses, but also for solutions to social and environmental problems. First, a brief introduction is given explaining why it is important today to have a correct definition of ES. Additionally, the concept of entrepreneur and its different types are defined to create a context and thus be able to talk about the subject. Likewise, a literature review is carried out to achieve a better understanding of an avant-garde concept such as this type of entrepreneurship. Finally, the article concludes with the most important points covered throughout the writing, in addition to a definition of entrepreneur and social entrepreneurship made after analyzing the information found.
\end{abstract}

Keywords:

Social Entrepreneurship, social entrepreneur, entrepreneur, business

\section{Resumen:}

El presente artículo comprende una revisión teórica del Emprendimiento Social (ES) debido al incremento gradual en la necesidad de nuevos negocios, pero también de soluciones a problemas sociales y ambientales. Primero, se da una breve introducción en la que se explica por qué en la actualidad es importante tener una definición correcta del ES. Adicionalmente, el concepto de emprendedor y sus diferentes tipos se definen para crear un contexto y así poder hablar acerca del tema. Así mismo se realiza una revisión de literatura para alcanzar un mejor entendimiento de un concepto vanguardista como lo es el este tipo de emprendimiento. Finalmente, el artículo concluye con los puntos más importantes abarcados a lo largo del escrito, además de una definición de emprendedor y emprendimiento social realizada tras el análisis de la información encontrada.

\section{Palabras Clave:}

Emprendimiento Social, emprendedor social, emprendimiento, negocio

\section{Introduction}

Social Entrepreneurship (SE) gradually begins to be heard more and more in the business world. Similarly, there are more studies, articles and cases that talks about the impact of SE in countries, companies, universities, etc.

SE is an activity that begins to be carried out in several places, the number of organizations that promote, help or reward undertakings like this has even increased. It can be said that there are many reasons to create SE because all the benefits that gave to all the parts. In general, helps to all type of countries boy fore the ones that are developing like Mexico, this activity is very important because of the contribution with the economic growth and GDP. SE is arousing with growing interest since it generates economic value but also social value that helps to respond social and environmental needs through innovate solutions [1].

The authors attribute success of SE because attack two problems with one action: SE combats social or environmental and economic problems. Social aid gives an enormous advantage over the other types of entrepreneurships since most are simple focused on

\footnotetext{
${ }^{a}$ Corresponding author, Universidad Autónoma del Estado de Hidalgo, Instituto de Ciencias Económico Administrativas, Área Académica de Administración, ORCID: https://orcid.org/0000-0002-3606-8010, Email: maria_martinez1078@uaeh.edu.mx

b Universidad Autónoma del Estado de Hidalgo, Instituto de Ciencias Económico Administrativas, Estudiante de la Maestría en Administración, ORCID: https://orcid.org/0000-0002-5511-9522, Email: mo449564@uaeh.edu.mx

c Universidad Autónoma del Estado de Hidalgo, Instituto de Ciencias Económico Administrativas, Área Académica de Administración, ORCID: https://orcid.org/0000-0002-7029-9779, Email: karina_valencia@uaeh.edu.mx
} 
solving problems related to generating profits for the benefit of the economy. It may be the case in which another type of entrepreneurship is confused with SE so this article can avoid this kind of confusions.

It is important to know that since the 90's the concept of SE start to be heard and talked but there is not a unique definition of the concept despite being studied in the recent years.

\section{Entrepreneurship}

Since a long time, the number of entrepreneurs has grown exponentially due to the power of market that exists nowadays. The activity of entrepreneurship it is very important in society, and it is a key part in the SE so is necessary to define it and understand well.

Starting from the basis, etymologically the word entrepreneur comes from the French word "entreprendre", which means "to do something" and, in the Middle Era it was originally used in the sense of a person who is active, who gets things done [2].

Richard Cantillon was the one who revolutionized the entrepreneurial concept for the first time in his work "Essai sur la nature du commerce en general" in 1755. Since ancient times, one of the factors by which and entrepreneur is identified by a risk. According Cantillon an entrepreneur was one who buys factor services at certain prices to combine them to produce a product and sell it at uncertain princes now at which he commits himself to his cost, namely it is not exactly known if the person will recover their investment. [2]

Schumpeter in 1934 was one pioneer about including the concept of innovation in an entrepreneurship environment because he believed that innovation was the central characteristic to entrepreneurial endeavor [3].

In 1982 Brockhaus has presented an excellent historic overview of the definitions of entrepreneurs, perhaps the most important factor from a societal perspective is the characteristic of innovation [3]. Theoretically the authors were right since that time because innovation goes hand in hand with entrepreneur.

Joseph Schumpeter said that entrepreneur needs to carry out his work together with other activities, since it would no make sense if there are no combination of factors.

On the other hand, Knight, Marshal and Clark assumed that an entrepreneur is a person with directive skills, all of them thinks that to be considered as an entrepreneur it is necessarily have a business vision but also a worker that can assume the roll of a Chief Executive Officer (CEO) [4].
Meir Kirzner stated that entrepreneurs are the balancing forces in the market process because they perceive opportunities, could advantage of them, make decisions to develop them and compete with other entrepreneurs who are interested in entering market and obtain benefits within a market economy [5]. On the other hand, Max Weber stated that a businessman needs to be in a capitalist world and the entrepreneurs are the protagonists of social change and are pillars of growth (p. 31).

To Zorrilla it is very important to not confuse entrepreneur with a businessman or an investor, he refers to them as: entrepreneur: who has the idea and the concept of a product or service to me made; investor: who makes the necessary capital available for the initial support and the start-up for the business; and last businessman: is the person who is in charge of managing and accounting the business [6].

At the very final, it is true that entrepreneur can be at the same time an investor and a businessman but to continue being considered as an entrepreneur, its necessary a constantly innovation.

Once all the previous concepts have been analyzed, it can be said that entrepreneur is a person that can identify certain needs of people and could generate transformations before anyone. It should be noted that being an entrepreneur is not always synonymous with success and there is always a risk.

\section{Entrepreneur Today}

Nowadays, all the markets around the world are made up of companies that at some point began as a simple idea an arise mainly for the idea of an entrepreneur.

The work they do is of the utmost importance since are a key element for economic growth, innovation and for increased competitiveness. A concept as important as that of "entrepreneur" today is still a case study worldwide due to all the variables that must do whit it.

At present, in a god part of developed and developing countries, the promotion of entrepreneurial education is encouraged due to its contribution to socioeconomic improvement [7].

The inclusion of entrepreneurial competence as a basic one awakens in educators and researchers in education an interest in learning about this emerging phenomenon that has transcended education. In the educational field in all the countries the development and inclusion of entrepreneurship is promoted, either as an independent 
subject or as a transversal competence, in all educational stages, from early education to higher education [7].

It can be identified that today many of the first word and underdeveloped countries are interested in promoting entrepreneurship from early stages due to the great contribution they make to each respective country.

Much of the business success entrepreneurs have achieved now, is thanks to their effort but also to the networks they have. Many successful entrepreneurs got to where they are now because of the help they got from others along the way [8].

One of the strongest indicators of networks is network size as the number of people whom the business owners known and that helps to create and build a sustainable and successful business, so business networking is one of the effective methods. Entrepreneurs, as active agents, will also develop their networks if they find it useful in their venture (p. 1,366).

So, it can be identified the network that today helps a lot to the entrepreneurs.

Derived from the question "What makes some entrepreneurs more successful than others?" There are three key points that make an entrepreneur achieve success today and they are curiosity, creativity, and commitment [9].

- Curiosity: The authors justified their answer about curiosity because the most successful entrepreneurs are curios about improving society.

- Creativity: The authors justified their answer about curiosity because the most successful entrepreneurs are curious about improving society.

- Commitment: The authors justified their answer about curiosity because the most successful entrepreneurs are fully committed to their task.

There is a model that includes these variables. It is known as "The Three C's Model of Entrepreneurial Success." In this model, basic traits are suggested to give rise to curiosity, creativity, and commitment, which in turn enhance entrepreneurial success. There is emphasis that this model is initial and provisional, and that as the empirical literature expands in the future, this model will be accordingly revised [10].
Figure 1. The Three C's Model of Entrepreneurial Success

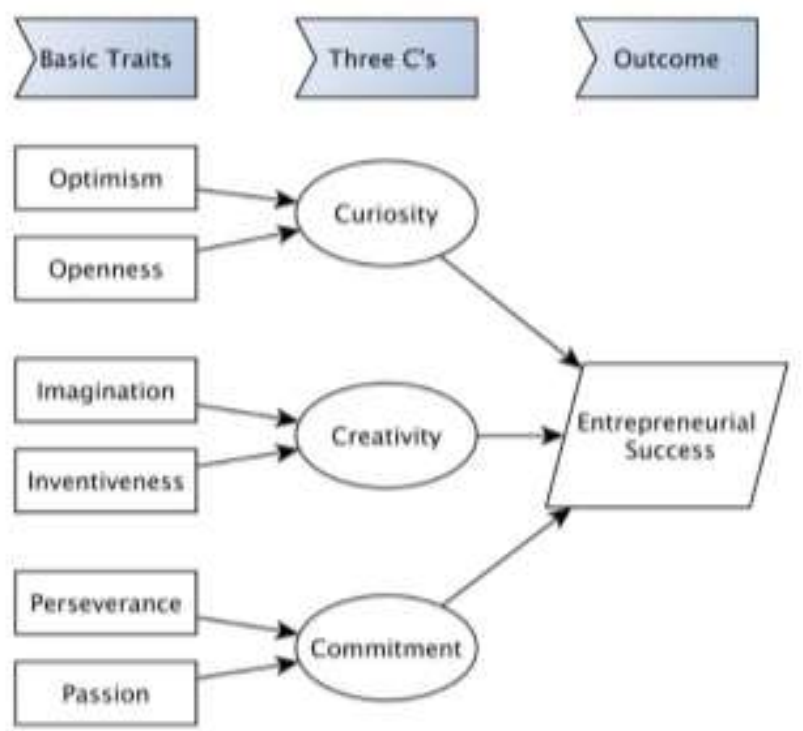

Source: Own elaboration with information of Raine and Pandaya (2019).

This model is important since, as has been seen, entrepreneurship usually carries a large amount of risk and even many of the new companies created can go bankrupt. The model presents what could be the keys for an entrepreneur to be successful in his business.

\section{Creativity}

Creativity in the entrepreneurial activity is key to success because enable an entrepreneur to develop innovate products, also enables an entrepreneur to quickly maneuver around production, servicing, and management barriers. Also, the authors argued that those who have a higher level or creativity are more active in responding to conflicts by adopting integrating and dominating styles of conflict management, they are better able to think around obstacles and generate alternative strategies.

Creativity is one of de C's and have as Basic Traits the imagination and inventiveness, resulting as an outcome the Entrepreneurial Success.

After studies carried out in different companies, the authors found a positive association between creativity and success, with higher creativity being associated with greater levels of entrepreneurial success. 
As a conclusion, it is mentioned that a successful entrepreneur is likely to need to find a balance between creative and convergent thinking, since not all ideas are viable no matter how good they are. It is necessarily having enough creative thinking to develop original ideas and an adequate convergent thinking to reduce the probability of failure at the time of implementation.

\section{Curiosity}

It is important to know what entrepreneurial curiosity is and how it can be measured. The intellectual curiosity of entrepreneurs results in them becoming completely absorbed by the question: What are the foundational traits that result in this entrepreneurial curiosity? The authors affirm that two personality traits commonly associated with entrepreneurial curiosity are optimism and openness.

Curiosity is one of de C's and have as Basic Traits the optimism and openness, resulting as an outcome the Entrepreneurial Success.

After studies carried out in different companies, the authors observed a positive significant association of moderate strength with a higher curiosity and a higher innovativeness.

As a conclusion, it is mentioned although there is a tentative evidence that curiosity can predispose to success, a largely unresolved question concerns the cross-cultural question of whether curiosity is related to success in all countries. Although business curiosity was found to be positively correlated with business openness, business curiosity was not significantly correlated with business growth. Therefore, different alternatives must be considered to achieve business growth after the creation of new innovative ventures with help of curiosity.

\section{Commitment.}

The commitment of entrepreneurs is key because currently the risk of failure associated with new startups companies is high. Another key point is resilience given the value offered to success, these factors can be divided in 3: personal, social, and external.

- Personal: There are two prominent sub-factors, self-efficacy, and perseverance.

- $\quad$ Social: There are important points like having a supportive family and professional relationships with experts in the field seem to have the most impact on whether an entrepreneur is successful.
- External: These factors consist of resource availability and rules and regulations within the entrepreneur's country are argued to enhance resilience.

Commitment is one of the C's and have as Basic Traits the perseverance and passion, resulting as an outcome the Entrepreneurial Success.

After studies carried out, the authors observed a significant positive correlation, showing that grittier and commitment entrepreneurs had companies with high venture performance a year later.

As a summary, it can be identified that this model is very important at the start of an enterprise, since for a person to be considered as an entrepreneur, they must not only start a business, is necessarily make it successful. The model includes three key processes- curiosity, creativity and commitment that can lend entrepreneurs to success in business world.

The 3 C's model is just provisional, and it is very important mainly in early stages. Finally, it's necessary to mention that as shown in figure 1 , each $\mathrm{C}$ must work combined with the others in order to obtain as an outcome the Entrepreneurial Success.

Since there are many variables that have to do with entrepreneurs, and many characteristics, is necessary to divide them [9]. These characteristics are the following:

\section{Administrative Entrepreneurship.}

The entrepreneurial activity to provide advantages and achieve the ability and competitive advantage use the traditional approach who is the administrative entrepreneurship that conduct research and development to develop products and improve technologies and it can also be considered as sharing all efforts by management and employees together to achieve it. So, thanks to tat wage employment usually does not generate enough resources and $s$ self-saturating must of people made innovations.

\section{Imitative Entrepreneurship.}

Due to an educated person has broadly two career options, one is called wage or salary employment, and the entrepreneurial employment under which people set up their new ventures.

This type of entrepreneurs who start their company because they do not want or cannot work in a salary employment are the most abundant, social and economic 
behavior are essential components of entrepreneurship as they contribute to the continuity of entrepreneurship when political, social and economic conditions are ideal and free from restriction, so entrepreneurship will succeed, and entrepreneurs can innovate on time.

\section{Acquisitive Entrepreneurship}

One of the characteristics or behaviors that describe this type of entrepreneur is that they learn from experiences and competencies and get benefit from them, is the leadership of the acquired business.

Acquisitive entrepreneurship is given thanks to the training of the entrepreneur and to the new acquisition on knowledge and experience, as this contributes to develop entrepreneurship and achieve technical capabilities.

\section{Types of Entrepreneurships}

As mentioned above, entrepreneurship is object of study and is in constant transformation so there are different types of entrepreneurships grouped in different classifications [11].

\section{Necessity Entrepreneurship.}

This is one of the most common, this venture is aimed at generating daily income to live, no for investments, whit low levels of income, utility and assets are obtained.

It is characterized by not having a planning or growth vision for the future, for this reason there is no added value or perspective of national or international markets.

\section{Traditional Entrepreneurship.}

There are enterprises that have growth due to their competitive structure but do not achieve goals sales, profitability, and high sustainability criteria.

It is characterized because its products and or services are not differentiated in some cases id does not have its workforce trained, they use little technologies, they are generally formalized.

\section{Dynamic Entrepreneurship.}

These are enterprises that have rapid, profitable, and sustained growth, having a representative sales level after a decade.
In this type of undertaking, there may be sublevels that will depend on the objective for which the company is created, such as:

\section{- $\quad$ Social Entrepreneurship}

- Inclusive Entrepreneurship

- $\quad$ Spinoffs

One of the key points that has gone hand in hand with entrepreneurship since its inception is innovation. The entrepreneur innovates by the new products ideas or re design with help of new technologies, productive processes, work, or business strategies [11].

Innovation is the implementation of a new and useful idea, and it is the realization that achieves a change in the system, with the purpose of improving and perfecting some aspect of its structure, content, or operation. Consequently, innovation turs ideas into useful, practicable and commercial product or services.

As such as entrepreneurships, innovation can be classified into categories according to different criteria, depending on the object of innovation, these are:

\section{Product Innovation.}

Applicate in goods and services, the highest level corresponds to the introduction of a totally new product on the market, then there are substantial and slight improvements.

\section{Process Innovation.}

Called Technological Innovations in Products and Processes (TPP) it covers activities of a very diverse nature (scientific, technological, organizational, financial, and commercial). Any business activity (production, organization, management, marketing, etc.)

\section{Innovation in markets.}

Consists of creating, expanding, or segmenting sales markets and creating or improving sources of supply for raw materials and products.

\section{Social Entrepreneurship}

Like the concept of entrepreneur, the concept of social entrepreneurship has also evolved and may have different definitions according to different authors. 
Social entrepreneurship (SE) is a type of dynamic entrepreneurship, as mentioned above and it is of utmost importance since it has the characteristic of helping both the one who offers the product or service, as well as the client, and depending on the type, it can also help the environment or social problems.

It can be considered as another type of enterprise, it has central elements of innovation and risk in the novel solution to a need or problem, offering customers different types of products or services.

However, social, and commercial entrepreneurship have a great contrast, the first difference between both types of entrepreneurships deals with social and / or environmental objectives over economic ones [12].

Dees (1998) stated the importance of knowing how to distinguish Business and Social Entrepreneurships, for Social, the mission is explicit and central, always reach goals in favor of environment and social problems and because of meeting its objectives there may or may not be an economic benefit, according to the constitution of the business [13]

Abu-Saifan (2012) purposed as a definition of Social Entrepreneurship like a mission driven individual who uses a set of entrepreneurial behaviors to deliver a social value to less privileged, all through an entrepreneurially oriented entity that is financially independent, selfsufficient, or sustainable [14].

Also, the definition combines four factors that make social entrepreneurship distinct from other forms of entrepreneurship such as:

- Are mission-driven, dedicated to serve their mission of delivering social value to the underserved.

- Act entrepreneurially through a combination of characteristics that set them apart from other types of entrepreneurs.

- Act within entrepreneurially oriented organizations that have a strong culture of innovation and openness.

- Act within financially independent organizations that plan and execute earned-income strategies.

\section{Characteristics of Social Entrepreneur}

Undoubtedly the most important key to carry out a social enterprise is the person who dares to carry out an enterprise of this type.

It is important to know for what reason and for what purpose the entrepreneur forms this type of enterprise and it is important to know its characteristics.

According to Dees (1998) there are different requirements or characteristics for an entrepreneur to be classified as social one [13]. There are the following:

- Adopting a mission to create and sustain social value (not just private value).

- Recognizing and relentlessly pursuing new opportunities to serve that mission.

- Engaging in a process of continuous innovation, adaptation, and learning.

- Acting boldly without being limited by resources currently in hand.

- Exhibiting a heightened sense of accountability to the constituencies served and for outcomes created.

Roa (2005) defined some characteristics of the social entrepreneur like innovation, strategy, and impact. [15]. There are the following:

\section{Innovation}

For these entrepreneurs there is always something to innovate in, they forget that everything is already invented and try to solve problems that directly affect a company through innovative ideas. social or environmental setting.

\section{Strategy.}

Each Social Entrepreneur can design their own strategy, but it can be stated that the only invariable condition in all of them is that their project has become a reason for life.

Impact.

The Social Entrepreneur knows how to make good alliances, especially with other social organizations. It is 
important for everyone to consolidate the models and increase the impact so that all the variables benefit.

For Martin and Osberg (2007) the Social Entrepreneur should be understood as someone who targets an unfortunate but stable equilibrium that causes the neglect, marginalization or suffering of a statement of humanity [16].

Also is the one who brings to bear on critical situations inspiration, direct action, creativity, courage, and fortitude and who aims for and ultimately affects the establishment of a new stable equilibrium that secures permanent benefit for the targeted group and society at large (p. 39).

Sen (2007), according to the Ashoka definition, Social Entrepreneurs are typically not socially responsible business leaders, directors of enterprises promoting sustainable development, managers of established nonprofit organizations, ideologues, or theoreticians but they are individuals with innovative solutions to society's most pressing social problems, visionaries and ultimate realists concerned with the practical implementation of their vision above all else [17].

Zhara, Gedajlovic, Neubaum and Shulman (2009) said that defining social entrepreneurship requires appreciating the motivations of individuals and groups who take the risks associated with conceiving, building, launching, and starting new organizations businesses models. In other words, this means that certain individuals with values, capabilities and skills will be attracted to SE, search for opportunities and innovative organizational responses to create social wealth [18].

SE encompasses the activities and processes undertaken to discover, define and, exploit opportunities in order to enhance social wealth, by creating new ventures or managing existing organizations in an innovative manner [18].

To Brinkerhoff (2009) social entrepreneur is someone who takes responsible risks on behalf of the people their organization serves [19]. There are the following:

- They are willing to take reasonable risk on behalf of people tat their organization serves.

- They are constantly looking for new ways to serve their constituencies and add value to existing services.

- They understand that all resource allocations are really stewardship investments.
- The weigh the social and financial return of each of these investments.

- They understand the difference between needs and wants.

- They always keep mission first, but know that without money, there is no mission output.

\section{Conclusions}

After all the information given above, it can be concluded that Entrepreneurship is necessary in order to generate economy power and even in rent time also to help social and environmental problems. Likewise, thanks to the collection of information the concept of entrepreneurship it was understood as the action of generating new ideas, carrying them out and being successful in business without stopping innovating.

On the other hand, it was found that the entrepreneur was the central axis of entrepreneurship and that it is necessary to differentiate it from the businessman and CEO, but it may be the case that in a company it can be all. Also, there was found as an important point into the environment of the entrepreneurs the Three C's Model in which the 3 C's (curiosity, creativity, and commitment) together whit their basic traits, after several studies there was found that usually it can be obtained an Entrepreneurial Success as an outcome.

Another key point around the entrepreneurship is their type since they can be classified as traditional or dynamic depending on the business. SE is within dynamic entrepreneurship and as equal as the concept of "entrepreneur" and "entrepreneurship" has evolved over time and there are authors who give their own definitions. Based on all the information previously described, SE can be defined as a branch of entrepreneurship that seeks to solve problems related to social and environmental aspects in which the economic benefit known as profit it will only occur as a consequence of meeting social or environmental goals and if the business type allows it.

Entrepreneurship is a powerful alternative to face or deal with economic problems due to aspects such as selfemployment, job creation, healthy competition generation and possible solutions to consumer needs. Inf entrepreneurship helps the above points, SE encompasses them too and it even helps to social or environmental problems, so it is a highly attractive alternative today due to the current situation. Therefore, social businesses are becoming more frequent and it's 
what makes the study of this subject avant-garde and has an exponential growth potential.

\section{References}

[1] Sánchez, J., Marín, S., Bel Durán, P. y Lejarriaga, G. (2018). Educación y formación en emprendimiento social: características y creación de valor social sostenible en proyectos de emprendimiento social. REVESCO: Revista de Estudios Cooperativos, 129, 16-38.

[2] Kaur, H., \& Bains, A. (2013). Understanding the concept of entrepreneur competency. Journal of Business Management \& Social Sciences Research, 2(11), 31-33

[3] Carland, J. W., Hoy, F., Boulton, W. R., \& Carland, J. A. C. (1984) Differentiating entrepreneurs from small business owners: A conceptualization. Academy of management review, 9(2), 354-359

[4] Tarapuez, E., \& Botero, J. J. (2007). Algunos aportes de los neoclásicos a la teoría del emprendedor. Cuadernos de administración, 20(34), 3963

[5] Azqueta, A. (2017). El concepto de emprendedor: origen, evolución e introducción. In Simposio Internacional El Desafío de Emprender en la Escuela del Siglo XXI (2017), p 21-39.

[6] Guerra, C. E. H., \& Restrepo, L. A. M. (2013). El emprendedor: una aproximación a su definición y caracterización. Punto de vista, 4(7).

[7] De Alda, A. A. D. (2019). Análisis del concepto 'emprendedor'y su incorporación al ámbito educativo. Teoría de la Educación. Revista Interuniversitaria, 31(1 (en-jun)), 57-80.

[8] Omar, C. M. Z. C. (2019) What Makes a Successful Entrepreneur? International Journal of Trend in Scientific Research and Development (IJTSRD), 3(4), 1365-1368.

[9] Raine, A. L., \& Pandya, M. (2019). Three keys to entrepreneurial success: curiosity, creativity, and commitment. Entrepreneurship Education, 2(3), 189-198

[10] Alsafadi, Y., Aljawarneh, N., Çağlar, D., Bayram, P., \& Zoubi, K (2020). The mediating impact of entrepreneurs among administrative entrepreneurship, imitative entrepreneurship and acquisitive entrepreneurship on creativity. Management Science Letters, 10(15), 3571-3576.

[11] Romero, X. A. V., \& Restrepo, S. O. (2016). Emprendimien-to innovación: Una aproximación teórica. Dominio de las Ciencias, 2(4), 346-369

[12] Bargsted, M., Picon, M., Salazar, A., \& Rojas, Y. (2013). Psychosocia characterization of social entrepreneurs: A comparative study. Journal of Social Entrepreneurship, 4(3)

[13] Dees, J. G. (1998). Enterprising nonprofits. Harvard Busines Review,76(1),54-66

[14] Abu-Saifan, S. (2012). Social Entrepreneurship: Definition and Boundaries. Technologies Innovation Management Review, 22-27.

[15] Roa, M. L. (2005). Definición y alcances del emprendimiento social. Representante de Ashoka en Colombia. Ashoka Emprendedores Sociales. $1-8$

[16] Martin, R. L., \& Osberg, S. (2007). Social entrepreneurship: The case for definition. Stanford Social Innovation Review, 5(2), 28-39.
[17] Sen, P. (2007). Ashoka's big idea: Transforming the world through social entrepreneurship. Futures, 39(5), 534-553.

[18] Zahra, S. A., Gedajlovic, E., Neubaum, D. O., \& Shulman, J. M. (2009). A typology of social entrepreneurs: Motives, search processes and ethical challenges. Journal of business venturing, 24(5), 519-532.

[19] Brinckerhoff, P. C. (2009). Mission-based management: Leading your not-for-profit in the 21 st century (Vol. 231). John Wiley \& Sons. 